\title{
PEMBELAJARAN KOOPERATIF TIPE NUMBERED HEAD TOGETHER (NHT) MATERI RELASI DAN FUNGSI PADA SISWA KELAS VIII SMPN 3 MAUPONGGO
}

\author{
Petronela Heriyana Putri ${ }^{1}$, Stefanus Notan Tupen ${ }^{2}$, Gregorius Taga ${ }^{3}$ \\ ${ }^{1}$ Program Studi Pendidikan Matematika, Universitas Flores, Jalan Sam Ratulangi, Ende-Flores-NTT \\ ${ }^{2}$ Universitas Flores, Jln. Sam Ratulangi, Ende-Flores-NTT \\ ${ }^{3}$ Universitas Flores, Jln. Sam Ratulangi, Ende-Flores-NTT \\ Email putriheryana@gmail.com
}

\begin{abstract}
This study aims to produce cooperative learning tools type Numbered Head Together (NHT) for Relationship and Function Material in class VIII students of SMPN 3 Mauponggo Satap 2019/2020 and to find out learning outcomes through the application of cooperative learning type of NHT, Relation and Function for students of SMPN 3 Satap Mauponggo. This research used in this research is experimental research. This study is the change that occurs between the pre-test and post-test values. Concomitant variable (Accompaniment): Student's pre-test score that must be reduced by covariance analysis. A sample is a portion (subsets) of a population. The sample in this study was 24 students of class VIII SMPN 3 Mauponggo Satap. The data analysis technique was obtained from the implementation stage using covariance analysis. Based on the results of the covariance analysis, it shows that $F$ count $=67.35$ is greater than $F$ table $=4.28$ with dk counting $=1$ and $d k$ denominator $=23$ giving a significant value, indicating that cooperative learning type Numbered Head Together (NHT) is considered to improve learning outcomes for related material and functions class VIII students of SMPN 3 Satap Mauponggo 2019/2020.
\end{abstract}

Keywords: numbered head together; relation and function

\begin{abstract}
Abstrak
Penelitian ini bertujuan : (1) Untuk menghasilkan perangkat pembelajaran kooperatif tipe Numbered Head Together (NHT) untuk Materi Relasi dan Fungsi pada siswa kelas VIII SMPN 3 Mauponggo Satap 2019/2020; (2) Untuk mengetahui hasil belajar melalui penerapan pembelajaran kooperatif tipe Numbered Head Together (NHT) materi Relasi dan Fungsi pada siswa SMPN 3 Mauponggo Satap 2019/2020. Jenis penelitian yang digunakan dalam penelitian ini adalah penelitian eksperimen. Variabel Perdiktor: X dalam penelitian ini adalah hasil pre-test siswa. Variabel Respon: Y dalam penelitian ini adalah perubahan yang terjadi antara nilai pre-test dan post-test. Variabel konkomitan (Pengiring): Skor pre-test siswa yang harus direduksi dengan analisis kovarian. Sampel adalah sebagian (himpunan bagian) dari suatu populasi. Yang menjadi sampel dalam dalam penelitian ini adalah siswa kelas VIII SMPN 3 Mauponggo Satap sebanyak 24 orang. Teknik analisis data diperoleh dari tahap pelaksanaan dengan menggunakan analisis kovarian. Berdasarkan hasil analisis kovarian menunjukkan $F_{-}$hitung $=67.35$ lebih besar dari F_tabel $=4,28$ dengan dk pembilang $=1 \mathrm{dan} \mathrm{dk}$ penyebut $=23$ memberikan nilai yang signifikan, menunjukkan bahwa pembelajaran kooperatif tipe Numbered Head Together (NHT) dinilai dapat meningkatkan hasil belajar untuk materi relasi dan fungsi pada siswa kelas VIII SMPN 3 Mauponggo Satap Tahun Ajaran 2019/2020.
\end{abstract}

Kata Kunci: numbered head together; relasi dan fungsi 


\section{PENDAHULUAN}

Mulyasa (2002:4) menegaskan bahwa pendidikan memberi kontribusi yang sangat besar terhadap kemajuan suatu bangsa dan membangun watak bangsa. Pendidikan mengidolakan kehadiran manusia yang berkualitas. Pendidikan senantiasa berupaya mewujudkan manusia yang berkualitas melalui berbagai kegiatan yang telah dirancang, diprogramkan, dan diaplikasikan sebab wujud manusia yang berkualitas membutuhkan proses pembelajaran yang cukup panjang. Pada hakekatnya, tidak ada pendidikan tanpa melalui proses. Proses pendidikan inilah yang menetukan kualitas seseorang (Trianto, 2007).

Soyomukti (2008 : 76) menjelaskan bahwa pendidikan merupakan cara untuk menciptakan kualitas manusia. Manusia yang berkualitas adalah manusia yang dapat menggunakan potensi fisik dan psikisnya untuk melihat dan merespons lingkungan sosialnya. Proses pendidikan dikosentrasikan memperhadapkan siswa pada masa depan yang penuh tantangan, yang didalamnya terdapat harapan dan kewaspadaan.

Dalam proses pembelajaran matematika diperlukan suatu model pembelajaran yang bervariasi. Artinya dalam penggunaan model pembelajaran tidak harus sama untuk semua pembahasan (Trianto, 2009). Sebab dapat terjadi bahwa suatu model pembelajaran tertentu cocok untuk satu pokok bahasan tapi tidak untuk pokok pembahasan yang lain. Hal tersebut belum dilakukan oleh sekolah SMPN 3 Mauponggo yang mengakibatkan hasil belajar matematika pada materi relasi dan fungsi dari tahun ke tahun menurun, karena KKMnya tidak pernah mencapai $60 \%$. Maka dari itu perlu diterapkan suatu sistem pembelajaran yang melibatkan peran siswa secara aktif dalam kegiatan pembelajaran, guna mengetahui hasil belajar matematika disetiap jenjang pendidikan. salah satu model pembelajaran yang melibatkan peran siswa secara aktif adalah model pembelajaran kooperatif.

Menurut Slavin (Taniredja, 2012 : 56) pembelajaran kooperatif dapat membantu siswa dalam mendefinisikan struktur motivasi dan organisasi untuk menumbuhkan kemitraan yang bersifat kolaboratif. Pengelompokkan siswa merupakan salah satu strategi yang dianjurkan sebagai cara siswa untuk saling berbagi pendapat, berargumentasi, dan mengembangkan konsep yang melandasi metode kooperatif. Konsep yang melandasi metode kooperatif yaitu : team rewards (tim akan mendapat hadiah bila timnya mencapai mencapai kriteria tertentu yang telah diterapkan), individual acountibility (keberhasilan tim bergantung dari hasil belajar individual dari semua anggota tim, equalo opprtunities for succes (setiap siswa memberikan konstribusi kepada timnya dengan cara memperbaiki hasil belajarnya sendiri yang terdahulu. Pembelajaran kooperatif memiliki beberapa tipe salah satunya adalah kooperatif tipe NHT.

Model pembelajaran NHT memiliki tupoksi mengasah kemandirian siswa. Pengembangan kemandirian siswa tercermin dari pelaksanaan model pembejaran NHT yang dilakukan dengan cara 
penomoran terhadap masing-masing siswa, sehingga setiap siswa bertanggung jawab atas materi yang diberikan (Zubaidi, 2011).. Sehingga model NHT ini mengacu pada keterlibatan total siswa (individual). Pembelajaran kooperatif tipe NHT ini memiliki keunggulan yaitu adanya sistem penomoran. Dengan adanya sistem penomoran ini memungkinkan setiap anggota kelompok berusaha untuk memahami jawaban atas pertanyaan yang diberikan sehingga setiap siswa menjadi lebih aktif dalam mengikuti proses pembelajaran. Tipe NHT menempatkan siswa di posisi sangat dominan dalam proses pembelajaran (Mangallo, 2016).

Model pembelajaran kooperatif NHT adalah pembelajaran yang didalamnya mengkondisikan para siswa untuk belajar bersama-sama didalam kelompok kecil untuk saling membantu satu sama lain dalam belajar. Pembelajaran kooperatif sangat cocok diterapkan pada pembelajaran matematika karena dalam mempelajari matematika tidak cukup mengetahui dan menghafal konsep- konsep matematika tetapi juga dibutuhkan suatu pemahaman serta kemampuan menyelesaikan persoalan matematika dengan benar dan baik. Melalui model pembelajaran ini siswa dapat mengemukakan pendapatnya, saling bertukar pikiran, saling bekerja sama jika ada teman dalam kelompok yang mengalami kesulitan. Hal ini dapat meningkatkan motivasi siswa untuk mengkaji dan menguasai materi pelajaran matematika sehingga nantinya akan mengetahui hasil belajar matematika siswa.

Hal tersebut sejalan dengan penelitiannya Ome (2016), menyimpulkan bahwa dari hasil penelitian diperoleh $F=86.08$ dengan dk pembilang $=1 \mathrm{dan}$ dk penyebut $=17$, memberikan nilai yang signifikan $(f$ tabel $=4,45)$ sehingga dapat dikatakan pembelajaran kooperatif tipe NHT efektif untuk materi persegi. Suri (2014) menyatakan bahwa dari hasil penelitian diperoleh hasil pengujian efek pembelajaran dan kelompok eksperimen terhadap respon $\mathrm{Y}$ setelah dimurnikan dari variabel konkomitan $\mathrm{X}$, diperoleh statistik $F=27,63$ dengan dk pembilang $1 \mathrm{dan}$ dk penyebut $=19$, memberikan nilai yang signifikan ( $f$ tabel $=4,15)$. Wua (2016) menyimpulkan bahwa hasil analisis kovarian diperoleh statistik $\mathrm{F}$ hitung $=56,79$ dan $\mathrm{F}$ tabel $=4,45$ dengan $\mathrm{dk}$ pembilang $=1 \mathrm{dan} \mathrm{dk}$ penyebut $=17$, memberikan nilai yang signifikan $(\mathrm{F}$ hitung $>\mathrm{F}$ tabel). Hal ini menunjukkan bahwa pembelajaran kooperatif tipe NHT memberikan hasil yang efektif.

\section{METODE}

Penelitian ini merupakan jenis penelitian eksperimen. Penelitian eksperimen merupakan metode penelitian yang digunakan untuk mencari pengaruh perlakuan tertentu terhadap yang lain dalam kondisi yang terkendalikan (Sugiyono, 2013:107). Penelitian ini diawali dengan penyusunan perangkat pembelajaran berupa Rencana Pelaksanaan Pembelajaran (RPP), Lembar Kerja Siswa (LKS), dan Tes Hasil Belajar (THB). 
Sesuai dengan jenis penelitiannya, maka rancangan penelitian yang digunakan adalah one groups design. Pada desain ini terdapat pre-test sebelum diberikan perlakuan. Dengan demikian hasil perlakuan dapat diketahui lebih akurat, karena dapat membandingkan dengan keadaan sebelum diberi perlakuan (Sugiyono, 2008: 110). Desain ini dapat digambarkan seperti pada tabel berikut ini

\section{Tabel 1. Rancangan Penelitian}

\begin{tabular}{|l|l|l|l|}
\hline Kelas & Pretest & Perlakuan & Posttest \\
\hline Eksperimen & $\mathrm{T}_{1}$ & $\mathrm{X}$ & $\mathrm{T}_{2}$ \\
\hline
\end{tabular}

Keterangan:

$\mathrm{T} 1=$ Pre-test pada kelas eksperimen

$\mathrm{T} 2$ =post-test pada kelas eksperimen

$\mathrm{X}=$ Perlakuan yaitu penerapan pembelajaran kooperatif NHT

$\mathrm{T} 1=\mathrm{T} 2$ (butir soal $\mathrm{T} 1$ sama dengan $\mathrm{T} 2$ )

Dalam penelitian ini yang menjadi populasi adalah siswa kelas VIII SMPN 3 Mauponggo Satap tahun pelajaran 2019/2020 dan sampelnya adalah siswa kelas VIII SMPN 3 Mauponggo Satap berjumlah 24 orang. Teknik yang digunakan adalah teknik simple random sampling atau teknik sampel acak sederhana dengan cara memberikan undian.

Teknik pengumpulan data yang digunakan dalam penelitian ini adalah teknik tes. Teknik tes merupakan kegiatan yang dilakukan oleh peneliti untuk mengetahui hasil belajar siswa dalam pembelajaran kooperatif tipe NHT untuk materi relasi dan fungsi pada siswa kelas VIII SMPN 3 Satap Mauponggo. Tes yang diberikan dalam bentuk essay test sebanyak 4 butir soal, masing- masing pre-test dan post- test. Soal yang digunakan untuk pre-test sama dengan soal post-test. Perancangan meliputi pemilihan media, pemilihan format, dan perancangan awal perangkat pembelajaran meliputi RPP, LKS, serta instrumen THB.

Validasi dilakukan terhadap perangkat pembelajaran dan instrumen test hasil belajar yang dikembangkan pada tahap perancangan. Ahli yang dimaksud disini adalah guru matematika SMP, validasi perangkat dan instrumen difokuskan pada isi, format, bahasa dan ilustrasi serta kesesuaian dengan pembelajaran NHT.

\section{HASIL DAN PEMBAHASAN}

Berdasarkan rumusan masalah maka langkah pertama yang dilakukan adalah merancang perangkat pembelajaran yang berdasarkan pada sintaks pembelajaran kooperatif tipe Numbered Head Together (NHT). Perangkat pembelajaran yang dimaksud adalah (1) Rencana Pelaksanaan Pembelajaran (RPP), (2) Lembar Kerja Siswa (LKS), dan (3) Tes Hasil Belajar (THB). Setelah selesai merancang perangkat pembelajaran, selanjutnya perangkat pembelajaran tersebut divalidasi oleh validator dalam hal ini yang menjadi validator adalah guru mata pelajaran. 
Sebelum dilaksanakan penelitian sebenarnya, peneliti melakukan uji coba perangkat pembelajaran pada kelas uji coba, dimana kelas uji coba ini karakteristiknya sama dengan kelas ekperimen atau kelas penelitian sebenarnya. Pada kelas uji coba berikan perlakaun yaitu melaksanakan pembelajaran kooperatif tipe Numbered Head Together (NHT), yang diawali dengan pemberian pre-test, melaksanakan pembelajaran sesuai dengan perangkat yang telah disusun, dan diakhir pembelajaran diberikan post-test.

Tujuan dari uji coba perangkat ini dilakukan untuk mengetahui jika ada kesulitan dalam melaksanakan pembelajaran berdasarkan perangkat yang sudah divalidasi, diharapkan agar kesulitan yang sama pada saat uji coba tidak terulang lagi pada saat dilakukan eksperimen pada kelas eksperimen, tujuan lainya adalah untuk menghitung secara statistik tentang validitas butir soal, reliabilitas, serta sensitifitas butir soal.

Dalam penelitian ini, kelas uji coba dilakukan pada siswa kelas VIII SMPS Batarende sebanyak 15 Orang, sedangkan penelitian sebenarnya dilaksanakan pada siswa kelas VIII SMPN 3 Mauponggo Satap sebanyak 24 orang. Setelah selesai melaksanakan uji coba perangkat, peneliti menganalisis hasil pre-test dan post-test untuk mengetahui validitas dan reliabilitas, dan sensitifitas butir adalah sebagai berikut:

Tabel 2. Validitas Butir THB

\begin{tabular}{|l|c|c|c|c|}
\hline No. Soal & $\mathbf{1}$ & $\mathbf{2}$ & $\mathbf{3}$ & $\mathbf{4}$ \\
\hline $\mathbf{r}_{\mathbf{x y}}$ & 0.73939 & 0.765227 & 0.482 & 0.862161 \\
\hline Validitas & Tinggi & Tinggi & Cukup & Sangat Tinggi \\
\hline
\end{tabular}

Keterangan:

No. Soal : Nomor soal 1,2,3,dan 4 adalah soal yang diberikan pada proses penelitian sesuai dengan tes hasil belajar (THB).

$r x_{y} \quad$ :Hasil perhitungan korelasi perbutir soal sesuai dengan Tes Hasil Belajar (THB). THB terlampir.

Validitas : Kriteria validitas perbutir soal sesuai rentang nilai $r x_{y}$.

Butir tes dikatakan valid jika mempunyai validitas cukup, validitas tinggi atau sangat tinggi. Berdasarkan kriteria kelayakan butir tes, maka setiap butir tes dikategorikan valid dan layak digunakan dalam penelitian .

Berdasarkan hasil perhitungan reliabilitas tes diperoleh koefisien reliabilitas sebesar 0.52 , kriteria "cukup". Jadi instrumen penelitian ini memenuhi kriteria reliabel dan dapat digunakan untuk penelitian selanjutnya.

Validitas cukup artinya nilai hasil perhitungan mencapai $0,400 \leq r x_{y}<0,600$, validitas tinggi artinya nilai hasil perhitungan mencapai $0,400 \leq r_{x y}<0,600$. Validitas sangat tinggi artinya nilai hasil 
perhitungan mencapai $0,800 \leq r_{x y} \leq 1,000$. Hasil perhitungan sensitivitas setiap butir disajikan dalam tabel 3 berikut:

Tabel 3. Perhitungan Sensitivitas Setiap Butir

\begin{tabular}{|c|c|c|c|c|}
\hline No. Soal & 1 & 2 & 3 & 4 \\
\hline Sensitivitas & 0.4624 & 0.48 & 0.5088 & 0.5376 \\
\hline Interpretasi & Peka & Peka & Peka & Peka \\
\hline
\end{tabular}

Keterangan :

No. Soal : Nomor soal sesuai dengan Tes Hasil Belajar (THB) yaitu nomor soal terdiri dari 1, 2, 3, dan 4.

Sensitivitas : Nilai uji sensitivitas perbutir soal sesuai dengan Tes Hasil Belajar (THB).

Interpretasi : Kriteria sensitivitas perbutir soal sesuai rentang nilai hasil uji sensitivitas.

Hal ini berarti semua butir tes memenuhi kriteria sensitif sehingga layak digunakan dalam penelitian eksperimen.

Berdasarkan hasil validasi dari validator, uji coba perangkat pembelajaran, dan analisis statistik menunjukan bahwa: Rencana Pelaksanaan Pembelajaran (RPP) mempunyai kategori baik dan dapat digunakan dengan tanpa revisi. Lembar Kerja Siswa (LKS) mempunyai kategori baik dan dapat digunakan tanpa revisi. Tes Hasil Belajar (THB) yang telah disusun mempunyai kategori baik. Deskripsi Eksperimen Perangkat Pembelajaran

Setelah selesai melaksanakan uji coba perangkat, langkah selanjutnya peneliti melaksanakan penelitian sebenarnya pada kelas Eksperimen dengan perangkat yang sama pada kelas uji coba. Langkah-langkah yang dilakukan sama seperti yang dilakukan pada kelas uji coba yaitu Pemberian pre-test kepada siswa dan Pelaksanaan pembelajaran kooperatif tipe Numbered Head Together (NHT).

Pelaksanan pembelajaran didasarkan pada RPP, LKS dan THB yang sudah baik. Adapun langkah-langkah yang dilalui adalah Kegiatan Awal seperti 1. Apersepsi, meliputi: a) Guru mengingatkan kembali materi yang telah dipelajari, b) Guru menyampaikan tujuan pembelajaran, c) Motivasi, meliputi: d) Guru menyampaikan pentingnya materi yang telah dipelajari dengan kehidupan sehari - hari.

Kegiatan Inti, seperti eksplorasi, meliputi: a) Guru membentuk kelompok belajar yang terdiri dari 3 - 4 orang, b) Guru menyajikan materi pembelajaran. Elaborasi Meliputi: a) Guru membagi LKS, b) Guru membimbing siswa dalam menyelesaikan soal LKS, c) Guru sebagai fasilitator siswa dalam mempresentasikan hasil kerja kelompok siwa, d) Guru memberikan penghargaan kepada kelompok yang skornya tinggi. Konfirmasi meliputi: a) Guru meluruskan semua kesimpulan yang dibuat siswa, b) Guru memberikan soal evaluasi dan memberikan penilaian terhadap hasil kerja siswa.

Terakhir adalah Penutup seperti : a) Guru memberikan penguatan atau penegasan kepada siswa tentang materi yang disajikan kepada siswa, b) Guru memberika n tugas individu yang berkaitan 
dengan materi yang disajikan kepada siswa dan c) Pemberian Post-test pada siswa. Adapun soal posttest yang diberikan adalah soal yang ada pada THB dan merupakan soal yang sama pada pre-test sebelumnya.

Setelah selesai melaksanakan penelitian sebenarnya, selanjutnya peneliti memeriksa hasil pretest dan post-tes pada siswa kelas VIII SMPN 3 Mauponggo Satap yang kemudian dianalisis dengan statistik Anova. Tujuannya adalah untuk mengetahui seberapa besar efek dari perlakuan dalam hal ini adalah pemberian pembelajaran kooperati tipe Numbered Head Together (NHT) yang diberikan kepada siswa. Hasil analisisnya adalah pada table 4 berikut ini:

\section{Tabel 4. Persiapan Analisis Data}

\begin{tabular}{|c|c|c|c|c|c|}
\hline Pre $(\mathrm{X})$ & Post & Perubahan $(\mathrm{Y})$ & Pre $(\mathrm{X})$ & Post & Perubahan $(\mathrm{Y})$ \\
\hline 20 & 95 & 75 & 25 & 80 & 55 \\
\hline 30 & 95 & 65 & 30 & 85 & 55 \\
\hline 25 & 90 & 65 & 25 & 75 & 50 \\
\hline 20 & 95 & 75 & 30 & 80 & 50 \\
\hline 20 & 100 & 80 & 35 & 70 & 35 \\
\hline 30 & 90 & 60 & 20 & 70 & 50 \\
\hline 25 & 95 & 70 & 25 & 75 & 50 \\
\hline 20 & 100 & 80 & 15 & 85 & 70 \\
\hline 30 & 95 & 65 & 25 & 75 & 50 \\
\hline 25 & 90 & 65 & 30 & 70 & 40 \\
\hline 30 & 90 & 60 & 25 & 85 & 60 \\
\hline 15 & 90 & 75 & 20 & 75 & 55 \\
\hline 290 & & 835 & 305 & & 620 \\
\hline
\end{tabular}

Keterangan:

Pre (X)-Test: Hasil tes siswa sebelum dilakukan pembelajaran kooperatif tipe numbered head together (NHT)

Post - Test: Hasil test siswa sesudah dilakukan pembelajaran kooperatif tipe numbered head together (NHT)

Perubahan (Y): Selisih antara hasil pre- test $(\mathrm{x})$ dan post-test atau selisih antara hasil test sebelum dilakukan pembelajaran kooperatif tipe numbered head together (NHT) dan sesudah dilakukan pembelajaran kooperatif tipe numbered head together $(N H T)$ 
Tabel 5. Daftar Anakova Metode Pembelajaran

\begin{tabular}{|c|c|c|c|c|c|c|c|c|}
\hline \multirow{2}{*}{$\begin{array}{c}\text { Sumber } \\
\text { Variasi }\end{array}$} & \multirow{2}{*}{ Dk } & \multicolumn{3}{|c|}{ JK dan Produk silang } & \multicolumn{3}{|c|}{ Dikoreksi } & \multirow{2}{*}{ F } \\
\cline { 3 - 8 } & & $\mathbf{Y}$ & $\mathbf{X Y}$ & $\mathbf{X}$ & $\mathbf{Y}$ & $\mathbf{D k}$ & KT & F \\
\hline $\begin{array}{c}\text { Antar } \\
\text { Kelompok }\end{array}$ & 1 & 1926.04 & -134.37 & 9.38 & & & & \\
\hline $\begin{array}{c}\text { Dalam } \\
\text { Kelompok }\end{array}$ & 22 & 1439.58 & -762.5 & 614.58 & 493.57 & 21 & 23.50 & \\
\hline Jumlah & 23 & 3365.63 & -896.88 & 623.96 & 2076.46 & 22 & & \\
\hline $\begin{array}{c}\text { Antar } \\
\text { Kelompok }\end{array}$ & & & & & 1582.89 & 1 & 1582.9 & 67.35 \\
\hline
\end{tabular}

Dari tabel ANAKOVA di atas, untuk menguji efek pembelajaran dalam kelompok eksperimen terhadap respon $\mathrm{Y}$ setelah dimurnikan dari variabel konkomitan $\mathrm{X}$, diperoleh statistik $\mathrm{F}=67.35$ dan $\mathrm{F}$ tabel $=4,28$ dengan $\mathrm{dk}$ pembilang $=1 \mathrm{dan} \mathrm{dk}$ penyebut 23 , memberikan nilai yang signifikan .

Tabel 6. Nilai Rata- Rata Koreksi Kelompok

\begin{tabular}{|c|c|c|}
\hline Perlakuan & Rt Dikoreksi & Rt Tdk Dikoreksi \\
\hline A & 68.80791 & 69.58333 \\
\hline B & 52.44209 & 51.66667 \\
\hline
\end{tabular}

Dari tabel tersebut di atas, tampak bahwa perbedaan rata-rata yang dikoreksi atau disesuaikan harga-harganya lebih kecil perbedaannya dari yang satu dengan yang lainnya jika dibandingkan dengan rata-rata yang tidak dikoreksi.

Model yang diperoleh dalam eksperimen adalah:

$$
\begin{aligned}
& \mathrm{Y}_{\mathrm{A}}=60.63-1.24 \mathrm{X}+68.81 \\
& \mathrm{Y}_{\mathrm{B}}=60.63-1.24 \mathrm{X}+52.44
\end{aligned}
$$

\section{Pemeriksaan Residual}

Setelah diperoleh nilai estimasi parameter, maka langkah selanjutnya adalah melakukan uji normalitas residual. Pengujian kenormalan residual menggunakan uji Kolmogorov-Smirnov dengan hipotesis sebagai berikut:

$$
\begin{aligned}
& \mathrm{H}_{0} \text { : Residual Berdistribusi Normal } \\
& \mathrm{H}_{1} \text { : Residual Tidak Berdistribusi Normal }
\end{aligned}
$$




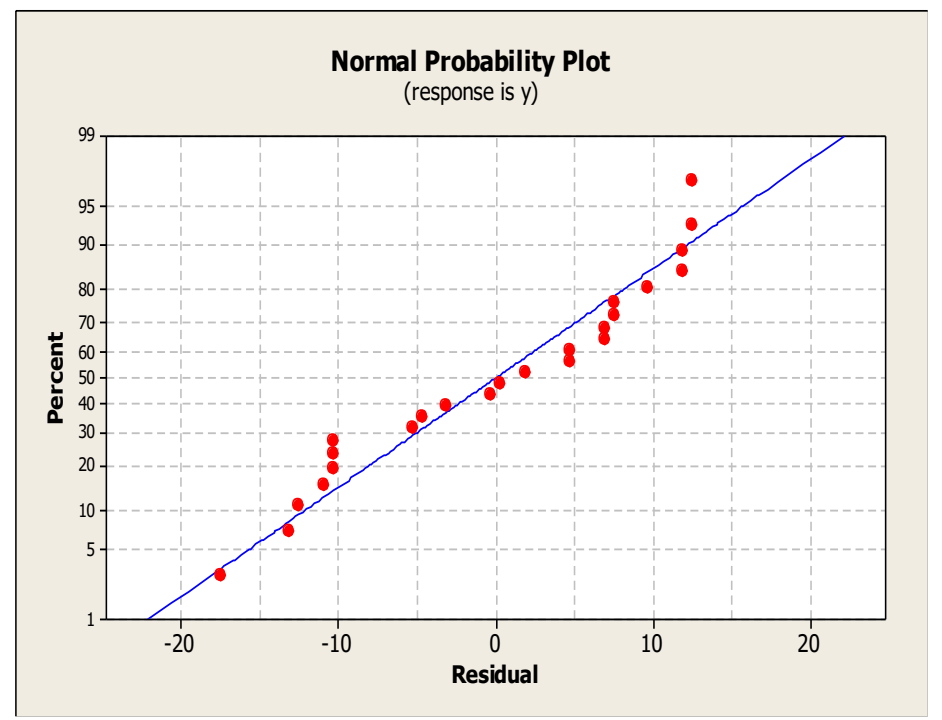

Gambar 1. Plot Residual

Plot normalitas residual menunjukkan tidak ada penyimpangan terhadap distribusi normal. Hal ini diperkuat dengan menggunakan uji Kolmogorov-Smirnov yang memberikan P-value $=0.273>$ 0,05 sehingga gagal tolak $\mathrm{H}_{0}$ atau residual berdistribusi normal.

\section{KESIMPULAN}

Berdasarkan hasil analisis dan pembahasan hasil penelitian, peneliti dapat menyimpulkan bahwa: perangkat pembelajaran kooperatif tipe numbered head together (NHT) untuk materi relasi dan fungsi dikategorikan baik. Perangkat pembelajaran yang dimaksud adalah: Rencana Pelaksanaan Pembelajaran (RPP), Lembar Kerja Siswa (LKS), dan Tes Hasil Belajar (THB).

Berdasarkan hasil analisis kovarian menunjukkan F_hitung $=67.35$ lebih besar dari F_tabel $=$ 4,28 dengan $\mathrm{dk}$ pembilang $=1 \mathrm{dan} \mathrm{dk}$ penyebut $=23$ memberikan nilai yang signifikan, menunjukkan bahwa Pembelajaran Kooperatif Tipe Numbered Head Together (NHT) Dinilai Dapat Meningkatkan Hasil Belajar Untuk Materi Relasi Dan Fungsi Pada Siswa Kelas VIII SMPN 3 Mauponggo Satap Tahun Ajaran 2019/2020.

\section{DAFTAR PUSTAKA}

Mangallo, Yulianto. (2016). Pengaruh Model Pembelajaran Kooperatif Tipe Numbered Head Together (NHT) Terhadap Minat dan Hasil Belajar Matematika Pada Materi Matriks Siswa Kelas XII IPA SMA Negeri 1 Nabire. Jurnal Ilmu Pendidikan Indonesia, 4(2)

Mulyasa. E, (2002). Manajemen Berbasis Sekolah : Konsep, Strategi, Dan Implementasi. Bandung : PT. Remaja Rodakarya. 
Nur dkk, (2016). Pengaruh Penerapan Model Pembelajaran Kooperatif Tipe Numbered Heads Together (NHT) Terhadap Hasil Belajar Matematika Siswa Kelas VII SMP Negeri I Tongkuno. Jurnal Penelitian Pendidikan Matematika.

Ome, Desiderius. (2016). Pendekatan Pembelajaran Kooperatif Tipe NHT Untuk Materi Persegi Siswa Kelas VII SMPN Satap Aerea Tahun Pelajaran 2015/2016 (Skripsi 2016). Ende . Universitas Flores.

Soyomukti, Nuraini (2008). Pendidikan Berprespektif Globalisasi. Yogyakarta : Ar-Ruz Media.

Sugiyono, (2008). Metode Penelitian Pendidikan: Pendekatan Kuantitatif, Kualitatif, Dan R\&D: Bandung: Alfabeta.

Sugiyono, (2013). Metode Penelitian Pendidikan: Pendekatan Kuantitatif, Kualitatif, Dan R\&D : Bandung : Alfabeta.

Taniredja. (2012). Model-Model Pembelajaran Inovatif. Bandung: Alfabeta.

Trianto. (2009). Mendesain Model Pembelajaran Inovatif - Profresif, Konsep, Landasan Dan Implementasinya Pada Kurikulum Tingkat Satuan Pendidikan (KTSP). Jakarta : Kencana.

Trianto, (2007). Pembelajaran inovatif Berorientasi Kontruktivistik. Surabaya : Prestasi Pustaka Publiser.

Wua, Feronika (2016). Pembelajaran Kooperatif Tipe NHT Untuk Materi Himpunan Siswa Kelas VII SMP Negeri 4 Bajawa Tahun Pelajaran 2015/2016 (Skripsi 2016). Ende. Universitas Flores.

Zubaidi, Z. (2011). Desain Pendidikan Karakter. Jakarta : Kencana Prenada Media 